\title{
ON THE COSMIC HUNT IN NORTH EURASIAN ROCK ART
}

\author{
Enn Ernits
}

\begin{abstract}
The article treats the possible reflections of the Cosmic Hunt myth in the rock art of Karelia, Siberia, the Far East and Northern Mongolia. The analysis comprises the more interesting groups of depictions, located on the coast of Lake Onega on Cape Peri Nos III, and on the northern Cape of Besov Nos, in Old Zalavruga by the White Sea, in the river basin of the Lena River in Central Siberia and elsewhere. A conclusion is reached that due to the fading of the contents of the myth and the specifics of rock art it is difficult, if not impossible, to prove the relevant connection. Therefore, it might be concluded that in the written materials many motifs of rock art have too easily been associated with the Cosmic Hunt myth.
\end{abstract}

Key words: Cosmic Hunt myth, Far East, Karelia, Mongolia, prehistoric religion, rock art, Siberia

The images of the Cosmic Hunt are relatively widespread within Northern and Central Eurasian, as well as American, peoples (Berezkin 2005: 109). The reflections of the discussed heavenly myth have also been suggested on several rocks in Northern Eurasia. The researchers of rock art have defined the myth in question differently. For example, M. Khlobystina (1971: 172) distinguishes two versions of the myth. In one case, a certain elemental force (at first in a zoomorphic, later in anthropomorphic form) pursues another elemental force, and in the other situation a certain monster is constantly hunting the Sun or the stars. In the extensively detailed book about Russian rock art the researchers, from Moscow, Ekaterina \& Marianna Devlet, treat the first version in the chapter with the title "Cosmic pursuit" («Космическая погоня»), the other version in the chapter named "Heavenly hunter" («Небесный стрелок»; cf. Devlet \& Devlet 2005: 116ff \& 124ff), without clearly distinguishing the concept 'cosmic hunt' (космическая охота) which is, however, used in both cases.

In the case of cosmic pursuit a certain animal, which epitomizes the everlasting darkness of the underworld, chases after and tries to destroy the source of light, the Sun. This might suggest either the alternating of day and night, or 


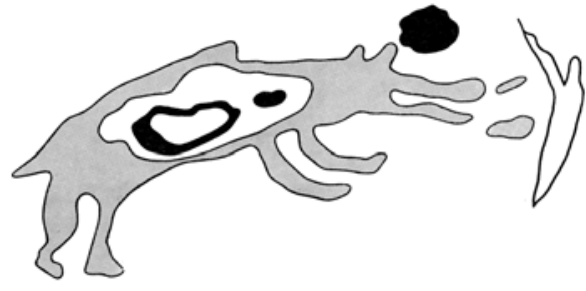

Figure 1. The sun eater of Tom (West-Siberia). Okladnikov \& Martynov 1972: 77.

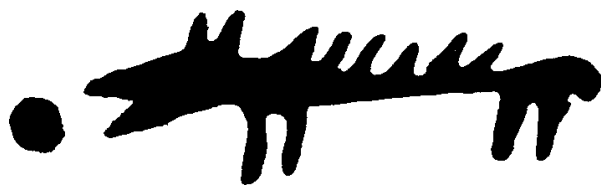

Figure 2. The sun eater of Arbi (Far East). Devlet \& Devlet 2005: 120.

a solar eclipse. The Devlets describe two motifs: in one case a circular sun (as a solar symbol) is depicted, and in the other case, an elk-shaped astral body. The first motif can also be found in Siberian rock art where the animal depicted in West Siberia, in the vicinity of the Tom River is obviously a bear, whereas, towards the East the image is more of a dragon-shape, similar to Chinese mythology (Fig. 1 \& Fig. 2). In these instances an animal figure in profile can be seen on the rock, with a circular disc or a circle around its muzzle in the majority of cases, or, infrequently, a star.

According to the Devlets, the subject matter of the 'heavenly hunter' comprises prehistoric tales and pictures in which 1) the Sami thunder god, featured as a giant hunter, chases the Sun - depicted as a rushing reindeer with golden horns (for further, see Ernits 1999: 37ff), 2) a hunter (culture hero) chases a predator who tries to catch a sun elk, and 3) a hunter (culture hero) kills several suns that concurrently shine in the sky and ravage the earth. In the current study, the Cosmic Hunt is treated solely as the second option suggested by the Devlets (Stith Thompsons folklore catalogue F59.2; see Berezkin 2005).

A serious problem in the research is whether, in rock art, it is possible to identify myths at all considering the relatively scarce data, and if yes, with what likelihood. The reason being the blurring and further development of ancient myths in the course of millennia, wherefore in rock art it mostly remains unclear as to who or what is depicted on a certain image. For example, the elk was an especially important animal in the Eurasian forest zone, both in the economic and cultural sense. The relevant plots, associated with the elk in rock art, have been divided into the following groups: 1) scenes connected with biology and behaviour of the animal (rut, the birth of an elk calf, migrations), 2) hunting scenes and 3) religious scenes (Markdorf 1998: 43-44). On the basis of the North Eurasian myth remains it is difficult to determine whether a certain elk figure marks the Earth, Sun, some constellation, theriomorphic 
fairy or an ancestor, etc. (see Danilov 2001; Okladnikov \& Mazin 1979: 53ff). However, in certain instances the theme of the Cosmic Hunt should be looked for in rock art, especially in cases where the images can be accurately identified and the composition (the scene) on the rock comprises a possibly larger number of characters.

\section{NORTH ASIAN SCENES}

Regarding North Asia, there are two compositions from the Far East, suggested by the rock art researcher Anatolii Mazin, as well as works of rock art found in Altai and the northern part of Mongolia that have been considered reflections of the Cosmic Hunt.

\section{Maia scene}

One of the scenes suggested by A. Mazin is situated in the Far East by the Maia River, the tributary of the Aldan River, and appears as a Late Stone Age ochre drawing. In the scene we can see an archer following an elk who has a faceshaped Sun, with surrounding beams, under its stomach (Fig. 3). On this occasion the speculation of the heavenly hunt is more likely than in many other cases, as the composition is complete: it has the hunter, the Sun and the elk and it is located in the area where the relevant myth is known. However, it should be borne in mind that in the scene in question the image of the Sun, or heliomorph, is secondary, i.e. later than the other figures (Okladnikov \& Mazin

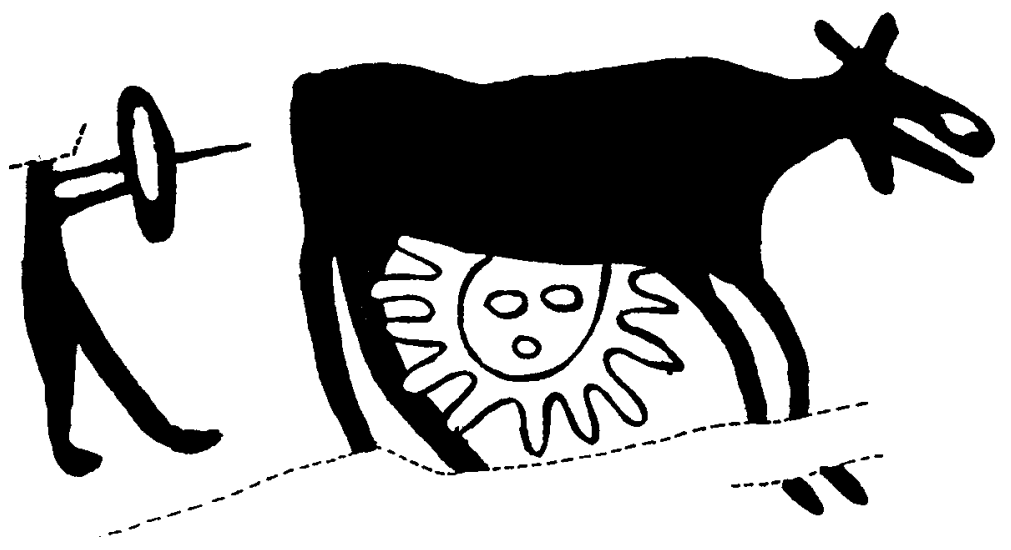

Figure 3. Maia scene (Central Siberia). Okladnikov \& Mazin 1979: 141. 
1979: 63). There are two possible explanations for this: whether the elk was considered a cosmic creature even without the heliomorph, or the animal became a heavenly or Sun elk secondarily.

The Komi ethnologist Nikolai Konakov has compared the Maia scene with the striped elk figures on Uralic rocks with the symbols of celestial bodies appearing as concentric circles in the vicinity (cit: Devlet \& Devlet 2005: 128, see also 118). However, a direct link between the two groups of petroglyphs cannot be proved, since the characteristics of hunting are missing in the Uralic rock art.

\section{Byrka scene}

Figure 4. Byrka scene (Far East). Mazin 1986: 240.

Another depiction described by A. Mazin is situated in the upper reaches of the River Amur, at the find place of Byrka. At first the hindquarters of a mammal have been drawn on the rock with ochre, and a face-shaped heliomorph, with beams touching the stomach of the animal has been added later, with a circle with four straight lines (reminiscent of the solar signs of Lake Onega) and another heliomorph in its vicinity (Fig. 4). An anthropomorph, depicted in a traditional style, is in contact with the latter. A. Mazin (1986: 139, 240) suggests that we are dealing with the reflection of the Cosmic Hunt whereas the anthropomorph could symbolize either the hunter Mani (more often Main in literature) who, according to the Evenk version of the myth, brings the hard-fought Sun back to the

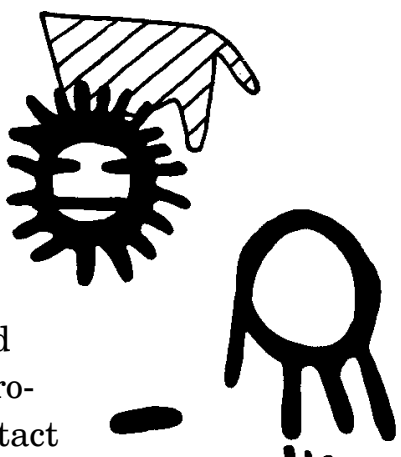
people. In the opinion of the current author the considering of the Byrka scene as an indication of the cosmic myth is quite questionable, since nothing refers to either the pursuit or hunt.

\section{Other North Asian scenes}

In Siberia, the depictions dated to the Bronze Age Okunevo Culture have been preserved where the pursuer incorporates a wolf-like creature with the head of a bear (?) and the legs of a bird. It chases the Sun, depicted as a bull, heading towards the West, which, according to the researcher, is referred to by solar signs associated with the image of the animal. They are surrounded by bull horns. Sometimes only one horn is connected with the Sun (Khlobystina 1971: 173). 
In the rock art of Altai and Mongolia there are numerous Bronze Age depictions of the species of Cervidae and Bovidae which carry the symbol of the celestial body on their horns. According to the researcher of rock art Eleonora Novgorodova (1989: 171-172) they represent the species of Cervidae who snatch the Sun and, in the course of time, may become horned monsters. This interpretation might not be accurate since we might be dealing with an elk-shaped Sun, i.e. the Sun elk or even somebody else. Indeed, J. \& M. Devlet (2005: 163ff) treat the horned creatures of Sun separately from the topic of the Cosmic Hunt.

E. Novgorodova (1989: 171) has considered another Bronze Age scene in Mongolia, in Arkhangai Aimak, as a representation of the Cosmic Hunt, supposedly depicting hunters aiming at the Sun and killing a species of Cervidae. Unfortunately, the named publication lacks a reference and therefore the present author cannot comment on the scene.

\section{KARELIAN SCENES}

The Neolithic engravings by Lake Onega, which appear in contact with the engravings depicting a celestial body, might be considered heavenly creatures (e.g. a single elk image of Cape Karitski and Cape Peri Nos VI, an animalheaded anthropomorph of Cape Peri Nos III) but these can hardly be connected with a definite myth. A scene on Cape Peri Nos might be considered one of the more plausible representations of the Cosmic Hunt myth, whereas the connection, of the scene on Cape Besov Nos with the myth, is more unlikely.

\section{Peri scene}

The current author considers the composition on Cape Peri Nos III by Lake Onega (see Fig. 5 on p. 66) as one of the most likely representations of the myth in question. However, there are also plenty of problems here. A serious challenge is the identification of the four-legged creature depicted from above. The interpretations of the being have been very different so far. Indeed, all researchers have agreed that we are dealing with a hunting scene. According to the writer and rock art researcher Aleksandr Linevskii (1939: 98) the composition under discussion depicts the springtime elk hunt with the help of an axe (!) and a pregnant dog. We should remember at this point that the author regarded rock art as an almost one-to-one representation of the real life of ancient man. Another Karelian rock art researcher, Vladislav Ravdonikas 


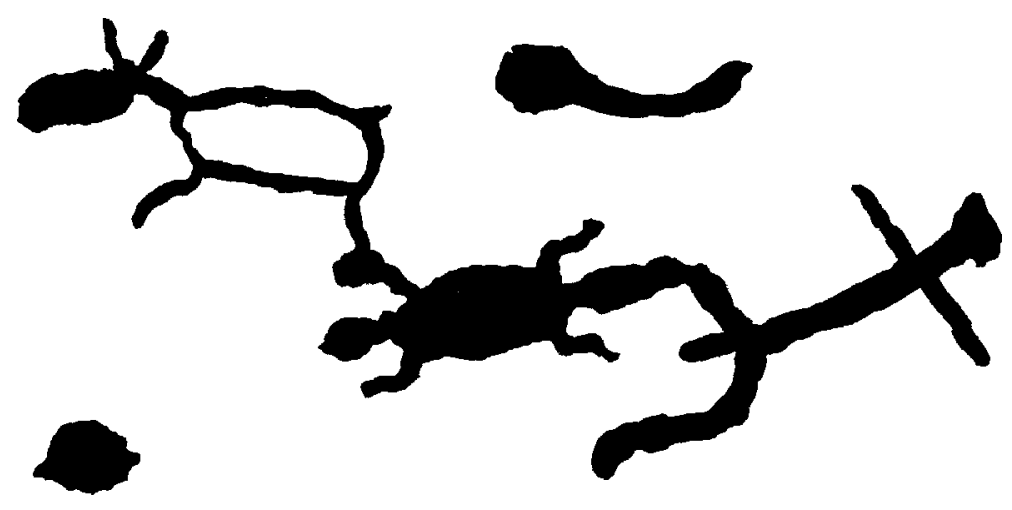

Figure 5. Peri scene. Ravdonikas 1936: Plate 11.

(1936: 59), who suggested the reflection of prehistoric religion in rock art, "grinned" over the simple-minded interpretation of Linevskii and sceptically believed the animal to be some sort of a lizard, however, for the latter suggestion the body of the creature was too chubby.

An ethnographer from Leningrad, K. Laushkin (1962: 250ff), stated that the axe was never used while elk hunting, and that the four-legged creature was too big, in comparison with an elk; instead, he identified the animal as a tail-less frog. Yet in this case it would be necessary to find an explanation as to why one of the anthropomorphs' rear legs is considerably shorter and fatter than the other. The researcher interpreted the whole scene as "the crime and punishment of an evil frog". He used one of the Sami etiological myths in his interpretation, according to which an evil frog, using a magic axe (!) would kill an elk-shaped sun every night. The hunter would thereafter slaughter the frog and dump its body in the fire. According to the researcher the earthly hypostasis of the Sun is depicted on the rock by a circle engraved slightly away from other petroglyphs. In the opinion of K. Laushkin, the scene involves benevolent cosmic forces, i.e. the victory of light over darkness and evil or, in other words the cosmic hunt. However, the proof material is not always appropriate, though connected with the celestial sphere (see Laushkin 1962: 256-258, 260). In our opinion the scientist is generally on the right path yet we are not dealing with a frog, but...

A zoologist from Petroskoi, Petr Danilov (1976: 113ff), regarded the figure under discussion as a beaver, and finally the Karelian rock art researcher Yuri Savvateev agreed with him, although Savvateev hesitated for years whether to consider the depiction a lizard or a frog, being influenced by his forerunners, or instead, a beaver (cf. Savvateev 1980: 149; 1983: 87 and Sawwatejev 1984: 87). In the opinion of the author of the current article, we are indeed dealing 
with a beaver (Ernits 1994a, 1994b). It should be added at this point that the archaeologist Natalia Chlenova (1989: 235) regards the Khanty beaver fratria or the property marks of the sir social group similar to the beaver images of Lake Onega; likewise, the flint figurines found from the Volga area should be added to this list. The beaver-like image of Cape Peri Nos III is not the only one among its kind. There are four beaver figures known among the petroglyphs of Lake Onega (Savvateev 1980: 141, 149-154): two on Cape Peri Nos III and one on the northern and western Cape of Besov Nos, yet the figures in these locations do not constitute any composition with other engravings.

The tail of the beaver constitutes a uniform whole with the rear limb of the figure with male characteristics. This allows suggesting a totemic connection. The combination of man and beaver can refer to a human beaver, totemic ancestor, a totemic hero descending from the beaver fratria. The connection with the rear limb seems to provide the key for understanding the association in several languages, incl. Estonian, between the words põlvnema 'descend', põlv 'knee' and sugupõlv 'generation' (cf. also Latin genus 'põlv' 'knee' and generatio 'põlvkond' 'generation'). K. Laushkin (1962: 252) considered it an unlikely possibility that the ancient artist had depicted the man's leg and the animal's tail as one piece, yet there are actually more combined depictions in the rock art of Lake Onega. Thus, in the northern part of the relevant area of distribution, we can see four combined engravings on Cape Swan and two in the mouth of the River Vodla, comprising the combined body parts of the images of an elk and a water bird (Fig. 6). In one of these cases the foreleg of the elk simultaneously forms the neck of the bird, and a part of the stomach in the other case (Poikalainen \& Ernits 1998: 95, 125, 173, 262, 293, 333). At this point, the present author has suggested the representation of the combined totem of the swan and elk fratrias (Ernits 1992: 117, 122). Such an interpretation does not allow considering the four-legged creature from Cape Peri Nos III as an enemy, as suggested by K. Laushkin. The fact that the beaver has not been engraved into the rock in profile, as the swan and elk depictions, but from above, has been conditioned by the fact that prehistoric people were apparently

Figure 6. The complex engraving on Cape Swan (Karelia). Poikalainen \& Ernits 1998: 125.

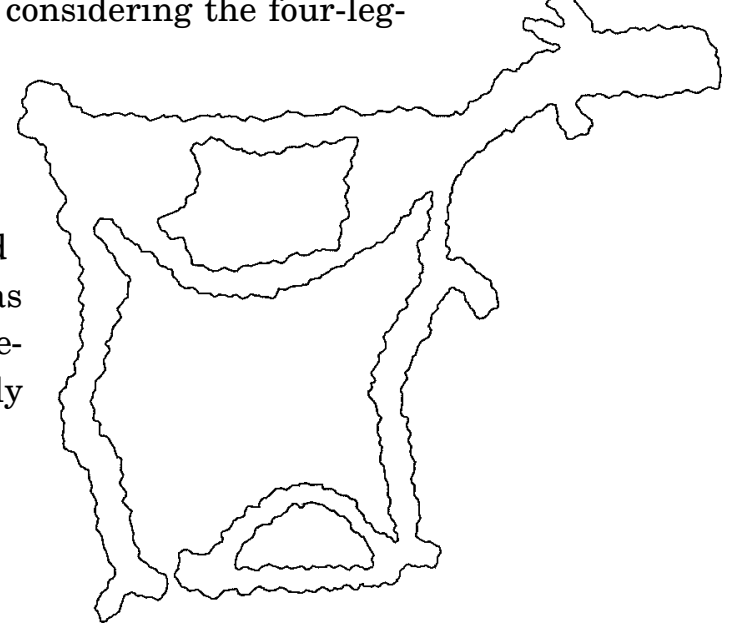


more familiar with the contours of the swimming beaver (see Savvateev 1980: 149).

On the basis of bone finds it is known that the beaver has been hunted in Karelia since Mesolithic times. Numerous amulets demonstrate that this mammal species has played an important role in prehistoric beliefs. Stone Age figurines have been found from Finland, Estonia, Lithuania and elsewhere. The beaver cult was widespread among the Finno-Ugrians back then (Chlenova 1989). The connection by means of the tail might indeed refer to the significance of the beaver's tail. Namely, under their tales beavers have their scent glands where valuable secretion is produced. Whether the secretion was of any value already during the Neolithic period is unknown since the first records about using the secretion originate from Herodotus from the 5th century BC (Schrader 1917-1923: 139).

The anthropomorphic creature has been depicted very schematically (almost as a cross) wherefore nothing can really be said about its actions. Only the weapon in the "air" allows suggesting that it has "recently" been thrown. Unfortunately, a beaver-shaped culture hero is not familiar from the BaltoFinnic mythology. The reason might be that the prehistoric hunters' religion gave grounds for the farmers' religion. The weapon of the supposed hunter the club (nui) - is also a problem. There is no data about the ancient Baltic Finns having used this weapon, although the word itself is of general BaltoFinnic origin or supposedly dates back even to the Mari or Permian languages (SSA 1995: 235; cf. Finnish nuija). Commonly in myths the bow and arrows have been mentioned as the weapons of the Cosmic Hunt.

Which celestial body might be hidden behind the human beaver is absolutely not certain since the relevant Balto-Finnic myth has been preserved only in remnants. A similarly confusing case appears with the elk figure the head of which is turned to the west. What does it symbolize? On the basis of Siberian data, I have, in my earlier writings, related the figure to the Ursa Major rushing towards the west at sunset. Back then no Eastern European data was known. However, the above-said can, to some extent, be verified with the help of the magnificent myth catalogue compiled by the researcher of the past, Yuri Berezkin from St. Petersburg (Berezkin 2008). ${ }^{1}$

In Eastern Europe, Ursa Major has been depicted as an elk by the Sami, Mari, and extensively also by the Northern and Central European Russians who have apparently acquired this image from Finno-Ugrians. However, we hardly have any information whether in Europe the elk has altogether been considered the object of the Cosmic Hunt. The scarce evidence of this might be the tale of the Finns and Karelians about an unfortunate hunt for a giant elk Hiisi who later became Ursa Major. Yet, in this particular instance and in the 
case of the following stories it is not absolutely sure whether we are dealing specifically with the hunt, the purpose of which was to arrange the actions of the Sun (see also Hautala 1947: 213-218).

Secondly, the Mari image should be mentioned according to which Ursa Major symbolizes an elk with calves and a hunter with a dog. The hunter is forced to forever circle on the vault of heaven because of killing the elks. It is possible that the cosmogonic myth has become etiological. Vague traces of the myth in question can be found among the Komi-Zyrians and the Chuvash people (the latter are the Finno-Ugrians who have changed their language). As we know, these stories have gradually become relatively obscure in content. Thus, it can only be cautiously suggested that the myth, where the elk was the object of the Cosmic Hunt, was formerly known by the Balto-Finnic people.

On the other hand, let us recall that according to the data by Castrén, in Sami mythology, the son of the Sun's daughter, Kalla parneh, representing Orion, with Ursa Major as a bow in his hand, pursued Cassiopeia which moved like an elk. In addition to the Sami, a similar story is known, as an arctic version of the Cosmic Hunt, among the Northeast Asian and North American peoples, which, according to the data of Y. Berezkin, refers to circumpolar connections (Berezkin 2005: 116-117, 119). This also shows that there are more variants besides the hunt for the Sun. The circular engraving which, in the opinion of K. Laushkin, depicted a fire in the composition of Peri, was previously considered the Moon by the present author, however, taking into account the myth as a whole, we might rather be dealing with the Sun. The connection with a solar symbol was suggested also by K. Laushkin (1962: 254).

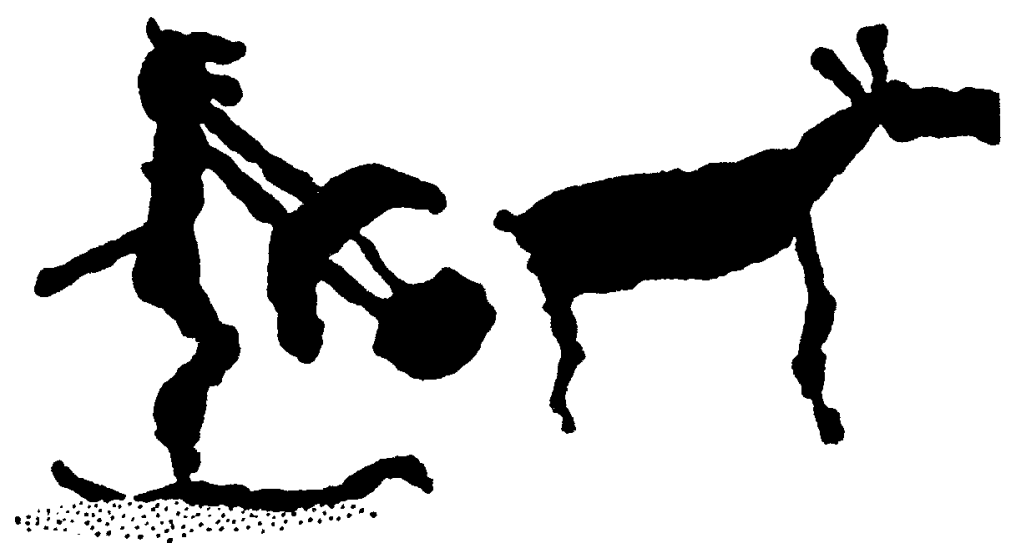

Figure 7. Besov Nos scene (Karelia). Ravdonikas 1936: Plate 22. 


\section{Besov Nos scene}

Could the Cosmic Hunt myth be represented by one composition on the northern Cape of Besov Nos on the cliff of Lake Onega (Fig. 7)? According to V. Ravdonikas (1936: 84-85) the composition depicts a profile of an anthropomorph with a tail, wearing an animal mask, with a lunar and a solar sign in his hand, riding on a snake and chasing a species of Cervidae, probably an elk. The head of the elk is turned towards the west, similarly to the image on Cape Peri Nos III. At this point it should be mentioned that a typologically similar (totemic?) anthropomorphic creature, depicted in profile and wearing an animal mask, with one cosmic sign in its hand, another near its rear limb and the third ahead of it, can be found on Cape Peri Nos VI (see Ravdonikas 1936: 79). This comparison has already been referred to by K. Laushkin (1959: 97). In any case, the latter composition does not represent the Cosmic Hunt myth.

At first V. Ravdonikas was ambiguous with regard to the species of the animal with a mask, specifying later that it was an anthropomorphic creature disguised as a bear (Ravdonikas 1937: 18). According to the researcher there is a certain benevolent totemic hero depicted on the rock, the protector of the clan or a tribe. V. Ravdonikas considered the fight of the two opposite particles (light and darkness, goodness and evilness, warmth and coldness) as the central idea of the scene. This suggestion, too distant from the matter, rightly called forth a somewhat ironic remark from A. Linevskii:

While looking at this figure I find it difficult to ascribe such a complicated mythology to the artist of the petroglyphs. This is undoubtedly a mythological creature but there is hardly any data for making conclusions about its fight with darkness (?) and evilness. (Linevskii 1939: 28)

Thus even A. Linevskii who usually looked for a rationalist origin in rock art, considered the anthropomorph a mythical character. However, the petroglyphs, interpreted as cosmic symbols by V. Ravdonikas, were continuously regarded as different kinds of traps by Linevskii. K. Laushkin (1959: 102), on the other hand, interpreted the scene under discussion as a symbolic offering to the Sun, whereas the offerer was a totemic ancestor who had taken light from the Sun and the Moon (in the form of the symbols of celestial bodies) and used this to help to combat spring-time famine and misery. In this case the reindeer would symbolize the victim.

$K$. Laushkin is convinced that the wavy line on the edge of the rock fissure does not represent a snake but a ski, and instead of the supposed tail the anthropomorph carries some sort of hunting requisite. Without mentioning the thoughts of Laushkin on this issue, Y. Savvateev (1983: 59) also considered 
these a ski and a hunting instrument, or a weapon. According to him the discussed composition might also include a lunar symbol, above the anthropomorph and the elk, and another elk with its head downwards. In the same place the scientist admits that he had been earlier mistaken when he interpreted the scene in the same way as A. Linevskii.

If we really are dealing with the scene of the Cosmic Hunt, the zooanthropomorph apparently uses skis which do appear in the myth stories of both the Finno-Ugric as well as other Nordic peoples. There are no more skiers among the petroglyphs of Lake Onega, however, they can be found among the depictions of the White Sea rock art.

By reason of partial similarity the mentioned scene of Lake Onega has been compared to a Stone Age scene of a skier in Rødøy in Nordland County, Norway. According to Nils Lid the anthropomorphic figure with horns could hold the same item as is visible on the petroglyph of Lake Onega. At this point $\mathrm{N}$. Lid suggested that both the Lake Onega, as well as the Rødøy skier, have been depicted with the remedy necessary for a shaman's trip to the underworld - the drum(s) (Lid 1956: 276, 282). The petroglyph of Nordland is not connected with a species of Cervidae. A skier, with a stick in his one hand, and a circular item in the other, is also depicted on a petroglyph discovered near the Tom River in West Siberia (Okladnikov \& Martynov 1972: 60).

The anthropomorph of Lake Onega is either wearing a mask or is a half human-half animal - a totemic creature, half predator. By the way, according to N. Lid (1956: 279), it is a wolf. It is not clear as to what does the elk stand for, since the celestial bodies (either the Moon or Sun?) are in the hero's hand. Did the hero get hold of these from their abductor, i.e. the elk? Provided we are really dealing with the Cosmic Hunt, it represents a totally different style and probably a different era.

Five researchers and five different interpretations! There is no principal difference whether a totemic ancestor or a certain hero has been depicted on the rock. Unfortunately, there is no sign of the activity of the anthropomorph on the rock. This enables offering completely different interpretations. The majority of the researchers are $a$ priori of the opinion that the ancient artist has depicted a hunting scene. However, hunt with snares has to be abandoned, since the numerous cosmic signs of various forms are at present no longer considered snares. Likewise, it is hardly believable that there are hundreds of depictions of shaman drums on the rock. Copious cosmic symbols have been referred to quite convincingly, although hardly with a 100 per cent probability. Therefore, the representation of cosmic myths on the rocks of Lake Onega is rather likely. The scene under discussion has some typological similarities with the sites of the above described rock art of the Okunevo Culture. 


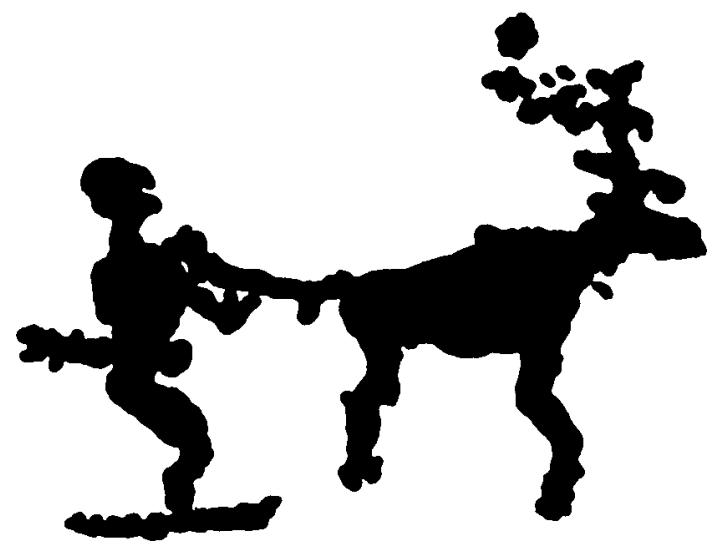

Figure 8. Old Zalavruga scene (Karelia). Ravdonikas 1938: Plate 15.

\section{Old Zalavruga scene}

The petroglyphs of the White Sea are significantly different from the Lake Onega depictions. The Devlets (2005: 133) have placed one scene, from the middle group of paintings in Old Zalavruga (Fig. 8), under the chapter "Heavenly hunter". According to the description by V. Ravdonikas (1938: 33, 35) the picture depicts a skier, attached to a high-antlered reindeer in front of him via a certain oblong artefact (a stick?). Similarly to the Lake Onega petroglyphs the animal is depicted with its muzzle turned towards the west. The scene could be interpreted as a representation of a cosmic myth only in the case where the small circle above the antler truly depicts a celestial body resp. the Sun. However, we cannot be sure of this. A similar skier (with a fragmentary bow?) and a reindeer with its head turned to the west are located in the vicinity. An interesting aspect is that the compositions are linked together by a chain of circles, short lines and irregular minute figures which might refer to the conceptual association of both scenes.

\section{IN CONCLUSION}

In the literature on rock art some scenes are far too easily regarded as the representations of the Cosmic Hunt. It should be admitted that there is hardly any ground to associate the scenes depicting elk or deer hunting with the Cosmic Hunt myth whereby there is no visible connection with the luminaries, and even more so if we are dealing with figures of archers on foot or on 
skis, without a (prey) animal. Likewise, it difficult to prove the Cosmic Hunt myth in petroglyphs where the respective attributes or hunting elements cannot be seen. The suggestion of the relevant theme is inhibited by the fact that the rock depictions are excessively schematic and do not allow unambiguous identification. In some cases it is possible to show that we are dealing with myths associated with celestial bodies, but which of these, remains unclear. The establishing of the relevant connection is more complicated as the myths have been fading in the course of time. Thus, it can be very cautiously suggested that from among the above discussed compositions it is the scene of Cape Peri Nos III by Lake Onega, and the one at the Maia River in Central Siberia that seem to be the most certain representations of the Cosmic Hunt.

Despite thumbing through numerous reference sources, the present author has found no information about the possible representations of the cosmic myth in Finnish and Scandinavian rock art. For example, among the numerous petroglyphs of Central Sweden, that depict a species of Cervidae, there is only one elk figure struck through with a (big) spear, although there is no hunter depicted in the vicinity (Forsberg 2000: 73). As becomes evident from the above-described, it is very difficult to prove the presence of a cosmic myth in rock art. While continuing the relevant research the possible thematic compositions of the whole world should be analyzed in great detail. But can they be found elsewhere?

\section{NOTES}

1 At this point I am indebted to Andres Kuperjanov who drew my attention to this publication.

\section{REFERENCES}

Berezkin, Juri 2005. Kosmiline jaht. Põhja-Ameerika müüdi Siberi variandid. [Cosmic Hunt. Siberian Versions of the North-American Myth.] Mäetagused, Vol. 30, pp. 109-130.

Berezkin, Yuri 2008. Tematicheskaia klassifikatsiia i raspredelenie fol'klorno-mifologicheskikh motivov po arealam: analiticheskii katalog. http://www.ruthenia.ru/ folklore/berezkin, last accessed on 15 Nov 2008.

Chlenova, Natalia 1989. Volga i Iuzhnyi Ural v predstavleniiakh drevnikh irantsev i finno-ugrov vo II - nachale I tys. do n. e. Doklad na Mezhdunarodnom kongresse finno-ugrovedov. Syktyvkar, 1985. [Volga and Southern Urals in the Imagination of Ancient Iranians and Finno-Ugrians during the $2{ }^{\text {nd }}$ Millennium and the 
Beginning of the $1^{\text {st }}$ Millennium BC. Presentation at the International FinnoUgric Congress. Syktyvkar 1985.] Sovetskaia arkheologiia 2, pp. 225-240.

Danilov, Oleg 2001. Kul't losia i olenia u finno-ugorskikh narodov: Istoki i razvitie. [Elk and Reindeer Cult among Finno-Ugric peoples.] Finno-ugrovedenie 2, pp. 36-56.

Danilov, Petr 1976. K istorii rasprostraneniia bobra v Karelii. [History of the Distribution of Beavers in Karelia.] Ekologiia ptits i mlekopitaiushchikh severa-zapada SSSR. Petrozavodsk, pp. 113-118.

Devlet, Ekaterina \& Devlet, Marianna 2005. Mify v kamne: Mir naskal'nogo iskusstva Rossii. [Myths in Stone: World of Rock Art in Russia]. Moskva: Aleteia.

Ernits, Enn 1992. The Purpose and Content of the Petroglyphs in the Onega Region. In: M. Hoppál \& J. Pentikäinen (eds.) Northern Religions and Shamanism. Ethnologica Uralica 3. Budapest \& Helsinki: Akadémiai Kiadó \& Finnish Literature Society, pp. 115-124.

Ernits, Enn 1994a. Kosmilisest jahist. [On cosmic Hunt.] Tartu Tähetorni kalender 1995. aastaks. Tartu: Tesserakt, pp. 70-75.

Ernits, Enn 1994b. Tema kosmicheskoi okhoty v onezhskikh petroglifakh. [The Theme of Cosmic Hunt on the Petroglyphs at Lake Onega.] In: G. Vilinbakhov (ed.) Mezhdunarodnaia konferentsiia, posviashchennaia 100-letiiu so dnia rozhdeniia professora V. I. Ravdonikasa: Tezisy dokladov. Sankt-Petersburg: Gosudarstvennyi Ermitazh, pp. 86.

Ernits, Enn 1999. Hõimlane verejõe tagant: saami muinaslood tootempõhjapõdrast 6. [Relative from across the River of Blood: Lapp Folk Tales about Totem Reindeer.] Mäetagused, Vol. 9, pp. 34-49.

Forsberg, Lars 2000. The Social Context of the Rock Art in Middle Scandinavia during the Neolithic. In: A. Kare (ed.) Myanndash. Rock Art in the Ancient Arctic. Rovaniemi: Arctic Centre Foundation, pp. 58-87.

Hautala, Jouko 1947. Hiiden hirven hiihdäntä: Vertaileva kansanrunoudentutkimus. Suomalaisen Kirjallisuuden Seuran toimituksia 234. Helsinki: Suomalaisen Kirjallisuuden Seura.

Khlobystina, Marianna 1971. Drevneishie iuzhnosibirskie mify v pamiatnikakh okunevskogo iskusstva. [Ancient Southern Siberian Myths in Art Monuments of the Okunevo Culture.] In: R. Vasil'evskii (ed.) Pervobytnoe iskusstvo. Otvetstvennyi redaktor. Novosibirsk: Nauka, pp. 165-180.

Laushkin, Konstantin 1959. Onezhskoe sviatilishche 1: Novaia rasshifrovka nekotorykh petroglifov Karelii. [The Sacred Place at Lake Onega 1. A New Attempt to Decode some Petroglyphs in Karelia.] Skandinavskii sbornik 4. Tallinn: Estonskoe Gosudarstvennoe izdatel'stvo, pp. 83-111.

Laushkin, Konstantin 1962. Onezhskoe sviatilishche 2: Opyt novoi rasshifrovki nekotorykh petroglifov Karelii. [The Sacred Place at Lake Onega 2. The Experience of Decoding some Petroglyphs in Karelia.] Skandinavskii sbornik 5. Tallinn: Estonskoe Gosudarstvennoe izdatel'stvo, pp. 177-298.

Lid, Nils 1956. Kalliopiirroksissa ja noitarummuissa kuvattuja hiihtäviä noitia. Kalevalaseuran vuosikirja 36. Porvoo \& Helsinki: Kalevalaseura, pp. 25-28.

Linevskii, Aleksandr 1929. K voprosu o petroglifakh Karelii (Besovy Sledki, Besov Nos i Peri Nos). [About the Petroglyphs in Karelia (Besovy Sledki, Besov Nos and 
Peri Nos).] In: V. Egorov (ed.) Sbornik Leningradskogo obshchestva issledovatelei kul'tury finno-ugorskikh narodnostei (LOIKFUN): Issledovaniia i materialy po finnougrovedeniiu 1. Leningrad: LOIKFUN, pp. 53-95.

Linevskii, Aleksandr 1939. Petroglify Karelii 1. [Karelian Petroglyphs 1.] Petrozavodsk: Kargosizdat.

Markdorf, Natal'ia 1998. Obraz losia kak sotsiokul'turnyi simvol neoliticheskoi epokhi lesnoi zony Evrazii. [The Image of Reindeer as a Socio-Cultural Symbol in the Neolithic Forest Zone of Eurasia.] In: I. Sher et al. (eds.) Mezhdunarodnaia konferentsiia po pervobytnomu iskusstvu: Tezisy dokladov: Kemerovo, 3-8 avg. $1998 \mathrm{~g}$. Kemerovo: pp. 43-44.

Mazin, Anatolii 1986. Taezhnye pisanitsy Priamur'ia.[Petroglyphs in the Taiga near the Amur River.] Novosibirsk: Nauka.

Novgorodova, Eleonora 1989. Drevniaia Mongoliia: Nekotorye problemy khronologii i etnokul'turnoi istorii. [Ancient Mongolia: Certain Problems regarding Chronology and Ethno-cultural History.] Moscow: Nauka.

Okladnikov, Aleksei \& Martynov, Anatolii 1972. Sokrovishcha tomskikh pisanits: Naskal'nye risunki epokhi neolita i bronzy. [The Treasures of Tomsk Petroglyphs: Rock Art of the Neolithic and Bronze Ages.] Pamiatniki drevnego iskusstva. Moscow: Iskusstvo.

Okladnikov, Aleksei \& Mazin, Anatolii 1979. Pisanitsy basseina reki Aldan. [Petroglyphs in the River Basin of Aldan.] Novosibirsk: Nauka.

Poikalainen, Väino \& Ernits, Enn 1998. Rock Carvings of Lake Onega: The Vodla Region. Tartu: Estonian Society of Prehistoric Art.

Ravdonikas, Vladislav 1936. Naskal'nye izobrazheniia Onezhskogo ozera i Belogo moria 1: Naskal'nye izobrazheniia Onezhskogo ozera. [Rock Art at Lake Onega and the White Sea 1: Rock Art at Lake Onega.] Trudy Instituta antropologii, arkheologii i etnografii 9: Arkheologicheskaia seriia 1. Moscow \& Leningrad: Akademii nauk SSSR.

Ravdonikas, Vladislav 1937. Elementy kosmicheskikh predstavlenii v obrazakh naskal'nykh izobrazhenii. [Elements of Cosmic Notions in the Form of Rock Art.] Sovetskaia arkheologiia 4, pp. 11-32.

Ravdonikas, Vladislav 1938. Naskal'nye izobrazheniia Onezhskogo ozera i Belogo moria 1: Naskal'nye izobrazheniia Belogo moria. [Rock Art at Lake Onega and the White Sea 1: Rock Art at the White Sea.] Trudy Instituta etnografii 10: Arkheologicheskaia seriia 1. Moscow \& Leningrad: Akademii nauk SSSR.

Savvateev, Yuri 1980. Onezhskie petroglify i tema zveria v nikh. [Petroglyphs at Lake Onega, and the Theme of Wild Animals Therein.] In: R. Vasil'evskii (ed.) Zveriv kamne. Novosibirsk: Nauka, pp. 136-158.

Savvateev, Yuri 1983. Naskal'nye risunki Karelii. [Karelian Petroglyphs.] Petrozavodsk: Kareliia.

Sawwatejev, Juri A. 1984. Karelische Felsbilder. Seemann-Beiträge zur Kunstwissenschaft. Leipzig: VEB E. A. Seemann Verlag.

Schrader, Otto 1917-1923. Reallexikon der indogermanischen Altertumskunde: Grundzüge einer Kultur- und Völkergeschichte Alteuropas. Berlin: W. De Gruyter \& Co. 
SSA 1995 = Suomen sanojen alkuperä: Etymologinen sanakirja 2: L-P. Suomalaisen Kirjallisuuden Seuran toimituksia 556 \& Kotimaisten Kielten Tutkimuskeskuksen julkaisuja 62. Helsinki: Suomalaisen Kirjallisuuden Seura \& Kotimaisten Kielten Tutkimuskeskus. 